\title{
DIE TIPOLOGIE AS 'N METODE VAN UITLEG VAN DIE OU TESTAMENT
}

\author{
DS. A. P. B. BREYTENBACH
}

Die belangstelling in die hermeneutiek van die Ou Testament die afgelope paar dekades het ook 'n nuwe belangstelling gebring in die tipologie as 'n moontlike wyse waarop die Ou Testament uitgelê kan word. Die doel van hierdie werkstuk is om kortliks in te gaan op die vraag of die tipologie of tipologiese eksegese wel 'n aanvaarbare en verantwoorde eksegetiese metode is, veral dan natuurlik met betrekking tot die Ou Testament. Dit sou verwaand wees indien daar nie aan die begin gesê word dat wat hier aangebied word, nie die oorspronklike werk van die skrywer hiervan is nie, maar wel die menings van verskillende geleerdes, veral Walter Eichrodt. ${ }^{1}$ )

Aan die begin moet ons eers vasstel wat met tipologie bedoel word. Alhoewel daar baie uiteenlopende gedagtes hieroor bestaan sou ons tipologie wel die beste as volg kon definieer:

Wanneer geskiedkundige feite (naamlik persone, handelinge, gebeurtenisse of instellings) as van God gegewe voorbeelde of tipes van komende, groter en meer volkome feite opgeneem word, dan het ons tipologie. ${ }^{2}$ )

Die woord tipologie is afgelei van die Griekse woord „tupos". Die woord "tupos" het in die eerste plek 'n baie konkrete betekenis: Wanneer ' $n$ mens byvoorbeeld jou vinger byt, dan is die merk (afdruksel) wat die tande maak op die vel 'n "tupos" van die tande wat in dié geval dan die ",antitupos” is. Verder ontwikkel dit die betekenisse van ,afdruk" of ,,afbeelding” (byvoorbeeld op munt) en „lompe gestalte". Dit word ook meer abstrak gebruik in die betekenis van ,algemene vorm", „model”, „tipe”, of „onnoukeurige uitbeelding". In die Nuwe Testament kom die woord veral in die meer abstrakte betekenisse voor.

Ook die woord (en begrip) ,antitupos" kom in die Nuwe Testament voor (vgl. byvoorbeeld 1 Petrus 3 vs. 21 ).

Dit is belangrik om daarop te let dat die "tupos" en die ,antitupos" nie in besonderhede ooreenkom, soos byvoorbeeld die afdruk van 'n foto nie. Dit handel hier om min, maar besonder belangrike analogië tussen twee groothede. Die besondere eienskappe van die "tupos" en die ,antitupos" is gewoonlik totaal

\footnotetext{
1) Vgl. die artikel van Eichrodt: „Ist die typologische Exegese sachgemässe Exegese?" in Probleme alttestamentlicher Hermeneutik, Band II van Theologische Bücherei.

2) R.G.G.
} 
verskillend en word dan ook heeltemal buite rekening gelaat. Wanneer die apostel dan byvoorbeeld in 1 Petrus 3 vs. 20 en 21 die gebeure by die sondvloed (as die „tupos") en die gebeure by die doop (as die ,antitupos") met mekaar vergelyk, dan gaan dit daaroor dat God in albei gevalle „,deur water heen" en belangriker nog ,deur die dood heen"3) gered het en nog red. Dit gaan dus, soos hierbo gestel om min, maar besonder belangrike analogieë,

Tipologie is iets heel anders as allegorie. Alhoewel ons soms tipologie aantref met allegoriese trekke en ook allegorie waarin die tipologie meespreek en alhoewel die grens tussen tipologie en allegorie in bepaalde gevalle soms moeilik getrek kan word, moet daar tog tussen hierdie twee metodes van uitleg onderskei word:

Allegorie soek gewoonlik na 'n geestelike betekenis, totaal los van die werklike gebeure. Die heil is hier 'n tydlose iets, los van geskiedkundige gebeure. Die allegoriese uitleg se resultate kan dan gewoonlik ook nie teruggevind word in die teks wat uitgelê is nie. In die allegorie is kleiner besonderhede dikwels belangrik en dit word deur die eksegeet met allerlei kunsgrepe só uitgelê dat dit inpas by 'n (vooraf) bepaalde betekenis wat aan die besondere gedeelte gegee wil word. Die beste voorbeeld van 'n allegorie is Augustinus se uitleg van die gelykenis van die barmhartige Samaritaan. Hiervolgens is ,'n sekere man" wat op pad is, die mens. Die rowers wat hom oorval is die duiwel en sy helpers wat die mens van die ewige lewe beroof. Die priester en Leviet wat verbygaan sonder om die man te help verteenwoordig vir Augustinus die Ou Testamentiese priesterdom wat nie in staat was om die gevalle mens te help nie. In die woord Samaritaan hoor Augustinus die Hebreeuse woord "shāmar" wat „bewaar" beteken. Omdat die Here ons Bewaarder is, is die Samaritaan dan niemand anders as Jesus Christus nie. Hy rig die gevalle mens weer op. Die twee pennings is die sakramente wat aan die kerk toevertrou is, ensovoorts.

Een van die belangrikste kenmerke van die allegorie is dat die resultaat van die uitleg totaal uitgelewer is aan die willekeur van die eksegeet. Daarom is die allegorie vir die huidige homiletiek nie net onaanvaarbaar nie, maar ook gevaarlik selfs al kom dit 'n paar keer in die Nuwe Testament voor (byvoorbeeld Galasiërs 4 vs. 22-26, en ook Markus 6 vs. 11-20, die uitleg van die gelykenis van die saaier. $\left.{ }^{4}\right)$ ).

3) Vgl. dr. A. van Selms, Genesis deel I, bls. 109.

4) Vgl. C. H. Dodd, The Parables of the Kingdom, bls. 2-4, 145-147. 
Tipologie is egter iets heel anders. Hier gaan dit oor geskiedkundige fakta. Die tipologie sien in die geskiedkundige gebeure 'n afkondiging van die heenwysing na die heilsgebeure van die nuwe tyd (aiōn) deur God Self. In die tyd van die afwagting is daar sekere dinamiese gebeure (handelinge van God) wat in hoofsaak "tipies" is van God se finale handelinge in die eindtyd. Ons vind die "tupos" as selfstandige gebeure in die tyd van die beloftes en die "antitupos" in die tyd van die vervulling; vanuit laasgenoemde gesien het die "tupos" in 'n sekere sin 'n voller en ryker betekenis.

\section{TIPOLOGIE IN DIE BYBEL.}

\section{Die Ou Testament:}

Alhoewel daar verskil van mening is by geleerdes, is dit tog redelik seker dat die tipologie se wortels teruggevind kan word in die Ou Testament: Die profete Hosea, Jeremia, Esegiël en Deutero-Jesaja sien in die uittog uit Egipteland 'n "voor-beeld" van komende gebeurtenisse. By die profeet Jesaja geld die ge. stalte van Dawid en ook die Sionstradisie as "tipies". Wanneer Deutero-Jesaja oor die "Ebed Jahwe praat, dan dien die figuur van Moses as voorbeeld. Dit was veral die sogenaamde eskatologiese profete wat hulle eie omstandighede en toekoms herken het in die vroeë geskiedenisse van die volk Israel.

\section{Die Nuwe Testament:}

Wanneer daar in ag geneem word dat die Rabbyne by hul uitleg van 'n skrifgedeelte dit woordeliks, simbolies of tipologies gedoen het, dan verbaas dit ons geensins dat tipologie ook in die Nuwe Testament voorkom, veral by die apostel Paulus wat self 'n rabbynse opleiding gehad het nie.

Alle gevalle van tipologie in die Nuwe Testament sal nie afsonderlik nagegaan kan word nie aangesien só 'n onderneming die bestek van hierdie artikel ver sou oorskry. Daarom word slegs die grondtrekke daarvan kortliks aangedui:

Die tipologie is in die Nuwe Testament geen uitgewerkte metode van uitleg nie. Daar is selfs geen vaste terminologie om dit aan te dui nie. Dit blyk duidelik uit die feit dat byvoorbeeld die woorde "tupos" en ,antitupos" by verskillende skrywers heel verskillend gebruik word. Eers by die kerkvaders (soos Pastor Hermas) word die tipologie 'n vaste metode van uitleg en selfs dán is daar nog geen vaste terminologie in dié verband nie.

Daar is by die skrywers van die Nuwe Testament wel 'n gemeenskaplike „tipologiese visie” op die Ou Testamentiese gebeure. Dit is naamlik dié benaderingswyse dat sekere geskiedkundige feite in die $\mathrm{Ou}$ Testament (veral dinamiese gebeure) beskou word as godgegewe voorbeelde van die groter en meer 
volkome handelinge van God in hulle eie tyd in die persoon en werk van Jesus Christus. Die vooronderstelling waarvan hulle uitgaan is dat die God van die Ou Testament die Vader van Jesus Christus is. Jesus van Nasaret is die Christus - dié Een wat die Ou Testamentiese heilsgeskiedenis voleindig. Hiérin, (die feit dat dit dieselfde God is wat in die geskiedenisse van die Ou Testament gehandel en in Jesus Christus beslissend opgetree het) lê vir die skrywers van die Nuwe Testament die onlosmaaklike verband tussen die Ou Testament en hulle eie tyd. Daarom kon húlle wat in die nuwe aiōn leef van geval tot geval in die heilsgeskiedenis van die Ou Testament ,tupoi" van hulle eie heilstyd herken. Hulle het Christus (sonder om Hom in die Ou Testament "terug te vind" of „in te lees") beter leer ken en verstaan in die handelinge van God met die aartsvaders en Israel.

Die Nuwe Testamentiese heil word nie in die Ou Testamentiese "tupoi" ingedra nie; hulle wil in die eerste plek iets sê oor die tyd van die Nuwe Testament en nié oor die Ou Testament nie. Ons moet begryp dat die Ou Testament vir hulle nie net 'n bewys of handboek was nie, maar 'n getuie van die heilsgeskiedenis wat in Christus voleindig is. Die gebeure van die Ou Testament was selfstandige gebeure wat vanuit die heilsgebeure rondom Jesus Christus ' $n$ voller en ryker betekenis het.

Daar is egter ook vir hulle in hierdie tipologiese ooreenkoms en betrokkenheid tussen Ou- en Nuwe Testament (wat ons sou kon noem) 'n styging. Die tyd van die Nuwe Testament is die eindtyd; die volheid van die tyd, daarom is daar 'n styging en is die ,antitupoi" in hierdie tyd meer volkome as die "tupoi" van vroeër (sonder om daarmee te kenne te gee dat laasgenoemde onvolkome was). Veral by die apostel Paulus en ook in die brief aan die Hebreërs word die „tupos” en „antitupos” uitdruklik teenoor mekaar gestel en die ooreenkoms, maar ook die styging aangedui.

Verder is dit belangrik om daarop te let dat die ,antitupoi" in die Nuwe Testament soms 'n positiewe voleinding van die "tupoi" is. 'n Voorbeeld hiervan is die kindskap van Abraham en die belofte van ' $n$ nageslag wat 'n positiewe voleinding vind in die gemeente van die Nuwe Testament as eiendomsvolk van God. In ander gevalle is daar 'n antitetiese opheffing van die „tupos" deur die ,antitupos". Voorbeelde hiervan is Christus wat die "tweede Adam" genoem word en die nuwe verbond wat gestel word teenoor die ou verbond by Sinai.

Met die sketsing van hierdie paar algemene grondtrekke van die tipologie in die Nuwe Testament kom ons nou by die vraag:

Is die tipologie 'n toelaatbare hermeneutiese metode vir die huidige eksegetse van die Ou Testament? 
In die eerste plek is bloot die feit dat tipologie in die Nuwe Testament voorkom geen argument om dit ook vir ons as 'n toelaatbare metode in die wetenskaplike eksegese te ag nie. Daar is baie ander dinge wat in die Nuwe Testament voorkom (byvoorbeeld die gedagte dat Dawid die digter van al die Psalms is) wat nie meer aanvaarbaar is vir die wetenskaplike eksegeet nie. Verder is dit ook belangrik dat ons sal onthou dat die tipologie in die Nuwe Testament geen hermeneutiese metode met vaste prinsipes is nie. As ons so 'n metode van uitleg wil „ontwikkel" sou ons die beginsels daarvan moeilik uit die Nuwe Testament kon aflei. Daarby beweeg die gevaar wat só wesenlik altyd op die agtergrond van 'n tipologiese metode van uitleg resloos uitgelewer is aan die willekeur van die eksegeet) ook altyd op die agtergrond van n' tipologiese metode van uitleg soos ons dit byvoorbeeld by die kerkvaders aantref. Daarom kan ons die tipologie nie as ' $n$ metode uitwerk waarmee elke saak in die hele Ou Testament benader kan word nie.

Die tipologie kan egter wel 'n dienende rol speel by ons uitleg van die Ou Testament. Ons behoort dieselfde „tipologiese visie” op die Ou Testament te hê as wat die skrywers van die Nuwe Testament gehad het: Die God wat in die Ou Testament handelend optree is dieselfde God wat in die Nuwe Testament (en ook in ons eie lewens) handel. Vanuit die nuwe aiōn sal die selfstandige gebeure van die Ou Testament ook vir ons 'n voller en ryker betekenis hê. Ook óns sal Christus en die Vader beter leer ken wanneer ons die Ou Testament weer goed gaan bestudeer. Ons moet dit egter doen sonder om Christus op allerlei wyses in die Ou Testament ,in te lees" of „terug te vind." Dit is veral gevaarlik om persone in die Ou Testament as tipes van Christus te wil sien. Ons moet in ons "tipologiese visie" die oog hê op die dinamiese gebeure in die Ou Testament en nie op persone nie.

Skrywer hiervan hoop en vertrou dat hierdie artikel ons weer opnuut sal laat besef dat daar nie 'n kits-metode is om elke teks in die Ou Testament mee te benader nie; maar dat dit alleen deur grondige studie (en daarmee bedoel ons van die Hebreeuse teks) moontlik is om hierdie deel van God se Woord verantwooordelik uit te lê en toe te pas. 